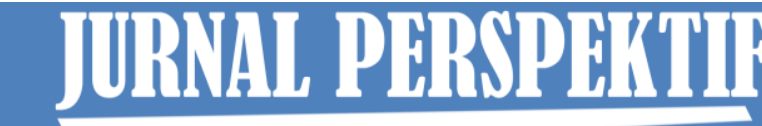

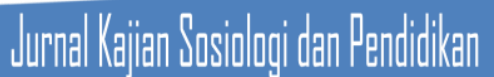

Jurnal Perspektif: Jurnal Kajian Sosiologi dan Pendidikan Vol. 3 No. 3 Tahun 2020

http://perspektif.ppj.unp.ac.id

Email: perspektif@ppj.unp.ac.id

ISSN: 2622-1748 (Online), 2684-902X (Print)

DOI: http://dx.doi.org/10.24036/perspektif.v3i3.300

\title{
Strategi Sopir Angkot dalam Menarik Penumpang di Kota Padang
}

\author{
Marti Nia Lestari ${ }^{1}$, Desi Nora AN ${ }^{2}$ \\ ${ }^{1,2}$ Universitas Negeri Padang
}

Email: martinialestari2@gmail.com, desinora@fis.unp.ac.id

\begin{abstract}
Abstrak
Penelitian ini bertujuan untuk mendeskripsikan strategi Sopir Angkot dalam menarik penumpang di Kota Padang. Teori yang digunakan dalam menganalisis penelitian ini adalah teori aksi yang dikemukakan oleh (Talcot Parson). Metode penelitian yang digunakan dalam penelitian ini adalah pendekatan kualitatif dengan tipe penelitian studi kasus serta teknik pemilihan informan dilakukan secara purposive sampling. Dalam pengumpulan data dilakukan dengan observasi pengamatan, wawancara mendalam, dan studi dokumentasi dengan teknik analisis data dari Miles dan Huberman. Hasil penelitian menunjukkan bahwa sopir angkot memiliki strategi dalam bersaing bisnis dengan sopir angkot lain yang bertujuan untuk menarik perhatian penumpang. Strategi yang dilakukan oleh sopir angkot yaitu: (1) Memodifikasi angkot (a) Modifikasi Eksterior: memasang sticker pada bagian badan angkot, menceperkan body angkot, memasang kaca film hitam (b) Modifikasi Interior: memasang perangkat audio, video dan sound system, memodif bentuk jok, menambahkan pernakpernik aksesoris pada bagian dalam angkot (2) Memiliki modal (3) Melayani penumpang dengan ramah tamah (4) Usia sopir dan tampilan sopir angkot.
\end{abstract}

Kata kunci: Penumpang, Sopir Angkot, Strategi

\section{Abstract}

This research is motivated by the presence of public transportation drivers in the city of Padang. This study was designed to describe the Angkot Driver's strategy in attracting passengers in the city of Padang. The research method used is qualitative, type of case study research. The selection of informants was carried out by purposive sampling with a total of 13 informants. Complete data collection, interviews, interviews, and study documentation. Theory Study This study was examined using rational choice theory proposed by James S. Coleman. Ratio choice theory focuses on actors. Actors choose as humans who have a purpose or have a purpose. Associated, actors who have goals and actions aimed at efforts to achieve that goal. Actors also think they must have a choice (or value, necessity). Rational choice theory ignores what is the choice or what is the source of the actor's choice. What is important is the fact that it is carried out for purposes that are appropriate to the level of actor's choice.

Keywords: Angkot Driver's, Passengers, Strategy

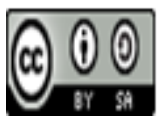

\begin{tabular}{|l|l|l|} 
Received: July 30, 2020 & Revised: August 14, 2020 & Available Online: August 15, 2020 \\
\hline
\end{tabular} 


\section{Pendahuluan}

Sektor informal merupakan lapangan usaha tidak resmi yang memberikan kesempatan kepada pencari kerja yang bersangkutan untuk menciptakan dan mengusahakan sendiri pekerjaan tersebut. Munculnya pekerjaan disekor informal untuk menampung pencari kerja akibat dari tinggiya arus urbanisasi terutama di negara-negara sedang berkembang (Astuti, 2010) .

Salah satu pekerjaan sektor informal adalah di bidang jasa transportasi. Sejauh ini transportasi baik transportasi modern dan transportasi tradisional merupakan hal yang sangat berarti bagi pembangunan. Ditinjau dari ilmu ekenomi mikro, transportasi merupakan jasa yang digunakan sebagai alat untuk memperoleh keuntungan-keuntungan ekonomis (Kamaludin, 1976) .

Transportasi merupakan tulang punggung perekonomian nasional, dan lokal baik di perkotaan maupun di pedesaan(Bruno, 2019). Hampir segala aktifitas manusia tidak dapat dipisahkan dan pasti membutuhkan transportasi, baik dalam penunjang mobilitas sehari-hari, pendistribusian barang dan jasa, maupun sebagai alat pemuas kebutuhan hidup dan sebagai pendukung kegiatan ekonomi masyarakat baik itu daerah pedesaan maupun perkotaan (Lantang, 2020). Transportasi merupakan komponen yang sangat penting di dalam sistem hidup dan kehidupan, sistem pemerintah dan sistem kemasyarakatan (Putranto, 2017) .

Sejak dahulu transportasi telah digunakan dalam kehidupan masyarakat, hanya saja alat angkutan yang dimaksud bukan seperti sekarang ini. Sebelum tahun 1800 alat pengangkutan yang digunakan adalah tenaga manusia, hewan dan sumber tenaga dari alam. Pengangkutan barang-barang dalam jumlah kecil serta menggunakan waktu tempuh yang lama sekali. Antara tahun 1800-1880 transportasi telah mulai berkembang dengan dimanfaatkan sumber tenaga mekanis seperti kapal uap, kereta api yang banyak digunakan dalam dunia perdagangan dan dalam tahun 1920 transportasi telah mencapai tingkat perkembangan pada puncaknya dengan sistem trasnportasi multi modal dan seiring berjalannya zaman alat transportasi berkembang pesat dengan kemajuan teknologi mutakhir (Salim, 2006). Transportasi yang sering digunakan oleh masyarakat adalah angkutan kota(angkot).

Angkutan kota (angkot) menjadi salah satu alternatif kebutuhan dalam menyikapi dinamika kota. Transportasi alternatif memberikan solusi sementara menjawab permasalahan yang ada. Tentu keberadaan transportasi diharapkan dapat menjadi efektitif dan efesien bagi para penggunanya (Jayanti, 2012). Angkot merupakan bentuk transportasi darat yang dimanfaatkan oleh masyarakat sebagai alat penunjang aktivitas sehari-hari. Angkot yang digunakan oleh masyarakat ini bermuatan sebanyak 12 orang penumpang 10 di bangku belakang dan dua tempat duduk di depan sopir dan dua tempat duduk. Penumpang merupakan orang yang menaiki transportasi atau angkot memiliki tujuan tertentu dan dengan sistem sewa atau bayar yang tarifnya sudah ditentukan kepada sopir angkot. Transportasi umum menjadi kebutuhan bagi masyarakat dalam menunjang aktivitas sehari-hari dan merupakan bagian yang tidak terpisahkan dari perkembangan kota(Soeparno, 2014) .Jika dilihat dari kondisi angkot umum pada hakikatnya yaitu tidak mempunyai banyak warna atau motif (hanya memiliki satu warna dasar), tidak ada modifikasi tambahan seperti memperpanjang dan memperpendek ukuran angkot, memceperkan skop pada rodanya serta memodifikasi pada bagian dalam angkot.

Angkot adalah sarana perhubungan dalam kota yang dikendarai oleh sopir. Di Kota Padang sendiri, terdapat berbagai macam jenis angkot dengan warna yang disesuaikan pada rutenya serta memiliki keunikan dan ciri khas masing-masing. Angkot Padang adalah salah satu moda transportasi yang banyak digunakan oleh masyarakat di Kota Padang. Angkot 
Padang beroperasi hampir setiap hari memberikan layanan kepada masyarakat kota Padang. Setiap waktu selalu ada penumpang dari berbagai kalangan yang turun naik alat trasnportai ini. Tarif angkot disesuaikan berdasrakan peraturan yang dikeluarkan oleh Dinas Perhubungan Kota Padang, serta menggunakan plat kuning yang mencirikan angkot sebagai transportasi umum (Fitri \& Putra, 2020) .

Angkutan umum merupakan salah satu mode transportasi massal (Purba, 2017). Penumpang bersifat massal sehingga biaya angkut dapat dibebankan kepada lebih banyak orang atau penumpang yang menyebabkan biaya per penumpang dapat ditekan serendah mungkin. Karena merupakan angkutan massal, perlu ada kesamaan diantara penumpang. Antara lain kesamaan asal dan tujuan. Kesamaan ini dicapai dengan cara pengumpulan diterminal dan tempat perehentian. Kesamaan tujuan bukan berarti kesamaan maksud. Angkutan umum massal atau masstransit memiliki trayek dan jadwal keberangkatan yang tetap. Pelayanan angkutan umum penumpang akan berjalan dengan baik apabila tercipta keseimbangan antara ketersediaan dan permintaan, oleh karena itu pemerintah perlu turut campur tangan akan hal itu.

Di Indonesia ada beberapa jenis transportasi atau pengangkutan yang dapat digunakan yakni melalui pengangkutan darat, air, dan udara dengan demikian dapat menjangkau seluruh pelosok kota yang ada di Indonesia (Elita et al., 1993). Beberapa jenis angkutan tersebut diharapkan dapat mendekatkan jarak antar kota yang ada di Indonesia. Sehingga memudahkan masyarakat dalam menjalankan aktifitasnya sehari-hari. Ada tiga jenis transportasi utama yang digunakan orang di perkotaan yaitu: angkutan pribadi (individual transit), seperti mobil pribadi, sepeda motor dan sepeda. Angkutan massal (mass transit), seperti kereta api, bis, angkot, dan sebagainya. Angkutan sewaan (para transit), seperti mobil sewaan, taksi yang menjalani rute tetap atau yang disewa untuk sekali jalan, dan sebagainya. Angkutan massal adalah salah satu alternatif kebijakan yang harus segera dilakukan untuk mengatasi permasalahan di perkotaan (Elita et al., 1993).

Salah satu bentuk transportasi massal yang digunakan masyarakat dalam menunjang aktifitas masyarakat adalah angkutan kota. Angkutan kota atau angkot merupakan sarana angkutan yang dapat mengangkut orang menuju tujuan tertentu dalam perkotaan dengan tarif berbayar sesuai dengan yang telah dikeluarkan oleh Dinas Perhubungan Kota Padang.

Di kota Padang dapat kita temui berbagai jenis angkot dengan rute berbeda yang dapat kita bedakan sesuai dengan warna dan jenis angkot yang sudah ditetapkan oleh Dinas Perhubungan Kota Padang. Selain dari bentuk dan warna angkot yang beragam angkot di Kota Padang dikenal dengan angkot Gaul karena bentuk dari angkot tersebut sudah dimodifikasi sedemikian rupa. Jumlah angkutan umum di kota Padang berdasarkan Departemen Perhubungan Kota Padang dalam Pusat Statistik Nasional pada tahun 2019, untuk kendaraan dengan jenis bus kecil sebanyak 2165unit dengan trayek sebanyak 73. Dapat kita lihat jumlah angkot berdasarkan jenis trayeknya, angkot trayek Pasar-Raya-Tabing sebanyak 15unit angkot, trayek Pasar Raya-Labor sebanyak 96unit angkot, trayek Pasar Raya-Kampus Unand Limau Manis sebanyak 97unit angkot dan pada trayek Pasar RayaBatas Kota sebanyak 328 unit angkot. Namun peneliti melakukan penelitian pada angkot Pasar Raya-Batas Kota yang berjumlah 328 unit angkot dengan kode trayek 419 disebabkan karena pada trayek ini merupakan jumlah angkot yang paling banyak dibandingkan dengan angkot trayek lain.

Dari data yang sudah di paparkan diatas dapat kita ketahui bahwa angkot di Kota Padang bukan lagi termasuk ke dalam kategori langka melainkan melebihi dari cukup. Khususnya pada trayek angkot Pasar Raya-Batas Kota terdapat jumlah angkot yang paling 
banyak tercatat di data Dinas Perhubungan Kota Padang pada tahun 2019. Dengan jumlah angkot yang banyak pada rute ini membuat penumpang tidak kawatir dengan susahnya mendapatkan angkot yang akan ditumpangi melainkan penumpang memanfaatkan kondisi ini dengan dapat memilih angkot yang mereka sukai.

Semakin meningkatnya angka persaingan antara sesama sopir angkot di Kota Padang dalam menarik penumpang yang membuat sopir angkot melakukan cara untuk menarik perhatian penumpang. Pada zaman yang semakin maju ini dapat dimanfaatkan oleh sopir angkot dalam mencermati celah-celah untuk dapat meningkatkan pelayanan mereka yakni dengan memberikan pelayanan tambahan sesuai target pelanggan sehinga menjadi daya tarik tersendiri untuk angkot mereka. Memodfikasi angkotnya sebagai salah satu cara yang dilakukan dalam menarik penumpang.

Berdasarkan hasil observasi dapat kita lihat bahwa lalu lintas yang dilalui angkot di sepanjang jalur trayek Pasar Raya - Batas Kota tidak teratur. Sering kali kita jumpai angkot dengan trayek ini mengemudikan angkot dengan ugal-ugalan tanpa memikirkan pengendara lainnya yang dapat membahayakan orang lain. Sopir yang mengemudikan angkot yang ugalugalan itu kebanyakan berusia muda yang memiliki ego sendiri dalam mengemudikan angkot. Angkot yang berwarna Oren ini ketika menaikkan maupun menurunkan penumpang suka berenti dengan tiba-tiba tanpa memberikan aba-aba seperti lampu sen kepada pengendara lain yang membuat orang pengendara yang ada dibelakangnya kaget lalu menekan rem dengan mendadak.

Penelitian yang relevan dengan penelitian ini adalah yang pertama, penelitian yang di lakukan oleh Indah Permata Sari 2016 judul "Alasan Remaja Memilih Angkot Modifikasi Trayek Pasar Raya-Siteba Kecamatan Padang Utara(Sari, 2016). Dalam penelitiannya ia mengugkapkan alasan remaja dalam memilih angkot modifikasi dapat dikelmpokkan menjadi dua bagian yaitu because motive dan in order motive: (1) Because motive; dari hasil temuan yang didapatkan di lapangan yang termasuk dalam because motive diantaranya yaitu: kepuasaan diri, seseorang akan merasa puas apabila keinginannya tercapai, angkot modifikasi sesuai dengan jiwa remaja yang menyukai hal-hal yang menarik yaitu dari tampilan angkot yang menarik. (2) in order motive; dari hasil temuan yang didapatkan di lapangan termasuk dalam in order motive yaitu: penampilan mewah angkot, dengan tampilan mewah angkot modifikasi sehingga remaja mendapatkan gaya/style dari kemewahan angkott tersebut, kerapian angkot, dan hiburan yang didapat di atas angkot.

Penelitian kedua terkait dengan penelitian yang dilakukan oleh Reynald Wynalda Putranto 2016/2017 tentang "Strategi Adaptasi Dalam Menjaga Eksistensi Mikrolet (Studi Deskriptif Mengenai Strategi Adaptasi dalam Menghadapi Persaingan Mikrolet di Kota Malang)". (Putranto, 2016). Dalam penelitiannya ia mendapati hasil bahwa strategi yang dilakukan oleh para sopir mikrolet adalah sebagai berikut: 1. Meningkatkan etos kerja, 2. Menambah waktu operasional kerja, 3. Mengutamakan efisiensi dan efektifitas kerja.

Penelitian ketiga terkait dengan penelitian yang dilakukan oleh Riko Putra 2013 judul "Sopir dan Angkot Gaul di Kota Padang( Studi Kasus; Sopir Angkot Gaul Daerah Tabing Trayek Pasar Raya-Labor Tabing di Kota Padang)" (Putra, 2007). Dalam peneltiiannya ia mendapatkan hasil bahwa munculnya fenomena angkot gaul di Kota Padang yaitu (1) Meniru Modifikasi bus kota, adanya keinginan pemilik angkot untuk meniru penampilan bus kota yang banyak menarik penumpnag dengan tampilannya. (2) Dampak peningkatan jumlah kendaraan bermotor. (3) Usia sopir, sopir angkot yang masih muda menginginkan angkot yang dikemudikannya sebagai angkot gaul. (4) Perkembangan audio visual. (5) Strategi 
bisnis, tingginya angka persaingan bisnis antar sesama angkot yang membuat sopir mengatur siasat dalam melakukan persaingan.

\section{Metode Penelitian}

Penelitian ini menggunakan jenis penelitian kualitatif yaitu suatu pendekatan yang menjelaskan realitas sosial yang ingin diteliti secara mendalam dengan mengunakan data kualitatif berupa kata-kata dan kenyataan. Dalam penelitian kualitatif ini data dan informan ditelusuri seluas-luasnya dan sedalam mungkin sesuai dengan variasi yang ada, sehingga dengan cara demikian peneliti mampu mendeskripsikan fenomena secara utuh(Bungin, 2010).

Jenis penelitian yang digunakan adalah studi kasus (case study) yaitu penelitian yang memusatkan perhatian pada fenomena-fenomena sosial umum yang nyata dalam kehidupan masyarakat. Metode ini menelaah mengenai suatu keadaan masyarakat yang dilihat dari persoalan atau kasus tertentu, baik dalam satu lembaga, kelompok maupun individu(Syani, 2007) .Teknik pemilihan informan yang peneliti gunakan dalam penelitian permasalahan ini yaitu teknik purposive sampling. Purposive sampling adalah teknik sampling yang digunakan oleh peneliti jika memiliki pertimbangan-pertimbangan tertentu dalam Teknik Pengumpulan Data dan pengambilan sampelnya(Fatinah, 2005). Jumlah informan pada penelitian ini adalah sebanyak 21 orang informan.

Teknik pengumpulan data yang pertama peneliti lakukan yaitu observasi partisipan, di sini peneliti terlibat langsung dengan objek yang akan diteliti yaitu tentang strategi sopir angkot dalam menarik penumpang, observasi dilakukan langsung dengan menaiki angkot. Wawancara yang dilakukan adalah wawancara mendalam (in deph-interview) merupakan teknik pengumpulan data yang didasarkan pada percakapan secara intensif dengan menggunakan pedoman wawancara atau catatan yang berisikan pemikiran yang merupakan pertanyaan mendalam yang akan ditanyakan pada saat wawancara berlangsung (Sugiyono, 2016).

Agar data yang diperoleh selama dilapangan valid dan akurat maka dilakukan dengan teknik triangulasi data, yaitu membandingkan dan mengecek kembali derajat kepercayaan suatu informasi melalui waktu dan alat yang berbeda (Moeleong, 2012). Triangulasi sumber yang dilakukan dengan memberikan pertanyaan yang sama kepada informan yang berbeda, yaitu informan sopir angkot, pemilik angkot dan penumpang dengan tujuan untuk memperoleh data secara akurat dan valid. Teknik analisis data menggunakan teknik analisis data dari Miles dan Huberman.

\section{Hasil dan Pembahasan}

Dari hasil penelitian dengan mewawancarai 19 orang informan yang terdiri dari 11 sopir angkot, 5 penumpang dan 3 orang pemilik angkot. Dengan tingginya jumlah angka pada angkot dengan jurusan trayek Pasar Raya-Batas Kota sebanyak 328 unit angkot, membuat para sopir angkot harus dapat memahami celah dari kebutuhan penumpang untuk bersaing dalam menarik simpati penumpang. Sopir angkot harus melakukan cara yang kreatif agar angkot yang dioperasikan bisa menjadi semenarik mungkin agar penumpang tertarik untuk naik angkot tersebut.

Penumpang adalah bagian terpenting bagi sopir angkot dalam melengkapi pekerjaan sebagai sopir angkot. Penumpang merupakan kunci utama yang membuat sopir angkot bisa memenuhi kebutuhan hidup. Tiada usaha yang akan terus berjalan tanpa adanya peran seorang penumpang, dan juga persaingan yang semakin ketat antara sesama sopir 
angkot membuat mereka harus bisa melakukan cara untuk mempertahankan keberadaannya. Sopir angkot dapat menggunakan strategi atau menyesuaikan keinginan dan kebutuhan penumpang, sehingga cara tersebut bisa membuat penumpang tertarik dengan angkot yang di operasikannya. Salah satu cara yang dilakukan oleh sopir angkot untuk meraih penumpang adalah dengan mendadani angkot angkot mereka (Yosritzal \& Aulia, 2016).

Mereka yang mengendarai angkot dari pukul 06.00 WIB samapi 20.00 WIB disebut sebagai sopir tetap, namun ada juga sebagian sopir serap yakni angkot yang dikendarai oleh remaja yang memulai aktivitas dari jam 13.00 WIB sampai 20.00 WIB. Bagi sopir angkot remaja, mereka bekerja untuk memenuhi kebutuhan untuk jajan sehari-hari. Bagi sopir angkot yang sudah berkeluarga mereka bekerja untuk menafkahi istri dan anak-anaknya. Selain itu mereka juga memikirkan cara untuk memenuhi setoran kepada Induak Samang, yang dimaksud dengan induak samang adalah orang yang memiliki angkot tersebut (Marcelena, Susilawati, Selisnawati, 2019). Strategi sopir angkot dalam menarik penumpang merupakan cara-cara atau tujuan yang ingin dicapai oleh sopir angkot dalam menarik perhatian penumpang di tengah ketatnya persaingan antar sesama sopir angkot di Kota Padang yang mana cara-cara yang digunakan sopir angkot tentunya berbeda-beda sesuai dengan kemampaun yang dimiliki. Tetapi, untuk mencapai tujuan tersebut strategi tidak berfungsi sebagai peta jalan yang hanya menunjukkan arah saja, melainkan harus mampu menunjukkan bagaimana taktik operasionalnya. "Angkot"berwarna oranye ini akhirnya dimodifikasi ulang oleh sopir dengan mengikuti gaya yang dianggap gaul,trendi dan disenangi banyak penumpang terutama anak muda(Masful, 2017) . Diantara strategi yang dilakukan sopir angkot dalam menarik penumpang, sebagai berikut:

\section{Dengan cara memodifikasi angkot}

Setiap orang mempunyai kecendrungan dalam melihat benda yang sama dengan cara pandang yang berbeda-beda dan melahirkan alasan yang berbeda pula. Angkot modifikasi adalah angkot yang sudah mengalami perubahan baik pada bagian Interior maupun Eksterior tanpa menghilangkan fungsi aslinya. Modifikasi angkot ini merupakan pilihan yang dilakukan oleh sopir angkot dalam mempertahankan keberadaan angkotnya demi persaingan bisnis dengan angkot lain, hal ini juga merupakan cara hanya untuk menarik penumpang secara selektif. Modifikasi yang dilakukan yaitu (a) modifikasi eksterior angkot: (1) memasang sticker pada badan angkot (2) merendahkan angkot dan mengganti velg racing (3) memasang kaca film hitam (b) modfikasi interior angkot: (1) memasang perangkat audio, video dan sound system (2) memodif bentuk jok (3) menambahkan pernak-pernik aksesoris di bagian dalam.

\section{Melayani dengan ramah tamah}

Ramah tamah harus dimiliki seorang sopir angkot terhadap penumpangnya. Antara sopir angkot dengan penumpang harus terjalin komunikasi dalam bentuk komunikasi antarpribadi (Mahardika, 2017). Masyarakat akan tertarik naik angkot pilihan mereka jika sopir angkotnya ramah kepada calon penumpang maupun penumpang. Karena dengan keramahan sopir angkot akan memudahkan terjalinnya keakraban antara sopir angkot dengan penumpangnya.

\section{Usia Sopir dan Tampilan}

Usia sopir juga mempengaruhi dalam ketertarikan penumpang. Karena jika sopir yang mengoperasikan angkot muda maka akan banyak diminati oleh penumpang baik dari kalangan pelajar sampai dengan kalangan dewasa karena dengan usia muda tentunya memiliki jiwa muda yang akan lebih mudah mengadaptasikan dirinya dengan penumpang 
terutama pada anak sekolahan. Namun, usia sopir yang sudah tua juga banyak diminati oleh penumpang terutama pada kalangan usia yang sudah tua juga.

\section{Memiliki Modal}

Untuk bisa melakukan cara agar angkot yang dimiliki terlihat lebih menarik, sopir angkot harus memiliki uang sebagai modal utama untuk bisa memodifikasi angkot mereka. Tentunya untuk mendapatkan itu semua sopir angkot tidak mengeluarkan sedikit uang tapi sampai puluhan juta rupiah untuk memodifikasi angkot di era persaingan yang semakin ketat ini. Untuk menganalisis strategi sopir angkot dalam menarik penumpang di Kota Padang, penelitian ini menggunakan teori aksi yang dikemukakan oleh Talcot Parsons. Parson menjelaskan bahwa istilah "action" menyatakan secara tidak langsung suatu aktifitas, kreatifitas, dan suatu progress penghayatan dari individu (Ritzer, 2004).

Parson mengemukakan bahwa, aktor mengejar tujuan dalam situasi dimana normanorma mengarahkannya dalam memilih alternatif cara dan alat yang digunakan dalam mencapai tujuan. Norma-norma itu tidak menetapkan pilihannya terhadap cara atau alat. Tetapi ditentukan oleh kemampuan aktor untuk memilih. Kemampuan inilai disebut Parsons sebagai voluntarisme. Voluntarisme dijelaskan sebagai kemampuan individu melakukan tindakan dalam arti menetapkan cara atau alat dari sejumlah alternatif yang tersedia dalam rangka mencapai tujuannya. Aktor menurut Voluntarisme ini adalah pelaku aktif dan kreatif, serta mempunyai kemampuan menilai dan memilih dari alternatif tindakan. Ini terlihat dari cara sopir angkot bersaing dengan sopir angkot lain dalam hal merebutkan hati penumpang. Tindakan memodifikasi angkot ini dilakukan oleh sopir angkot yang bertujuan untuk membuat angkotnya menjadi semenarik mungkin agar calon penumpang tertarik dan memilih untuk naik angkot tersebut. Tidak hanya memodifikasi angkot yang menjadi tindakan yang dilakukan oleh sopir angkot, tetapi strategi lain juga dilakukan oleh sopir angkot seperti: menunjukkan sifat ramah tamah kepada penumpang, usia sopir dan tampilan dari sopir angkot dan memiliki modal. Tentunya semua cara yang dilakukan tersebut memiliki tujuan untuk menarik perhatian penumpang yang akan berpengaruh terhadap pendapatan yang diperoleh sopir angkot dalam mengoperasikan angkot itu.

\section{Kesimpulan}

Berdasarkan hasil penelitian yang peneliti lakukan dilapangan dapat disimpulkan bahwa sopir angkot memiliki berbagai cara yang dilakukan untuk bersaing bisnis dalam menarik perhatian penumpang dnegan angkot lainnnya. Strategi yang digunakan oleh Sopir Angkot dalam menarik perhatian penumpang di Kota Padang, meliputi strategi terpenting adalah dengan memiliki modal, memodifikasi angkot pada bagian eskterior dan interior, menunjukkan sifat ramah tamah kepada penumpang, usia dan tampilan dari sopir angkot. Strategi yang dilakukan oleh sopir angkot yang memiliki modal adalah melakukan modifikasi pada angkot mereka agar terlihat lebih menarik bagi penumpang dan menciptakan rasa nyaman terhadap penumpang yang akan naik angkot itu.

Strategi lain yang digunakan oleh sopir angkot adalah melayani penumpang dengan ramah tamah dengan merayu penumpang lemah lembut akan membuat hati penumpang tersentuh lalu tertarik untuk naik angkot tersebut. Selain itu usia dari sopir angkot juga mempengaruhi penumpang dalam memilih angkot karena tampilan dan gaya dari sopir akan memikat hati penumpang terutama pada anak sekolah.Hal ini memberikan dampak kepada pendapatan sopir angkot perharinya, karena semakin banyak penumpang tertarik dengan angkot yang dioperasikannya maka akan memberikan keuntungan bagi sopir angkot tersebut dalam pendapatan yang di dapat perharinya. 
Marti Nia Lestari, Desri Nora AN Strategi Sopir Angkot dalam Menarik Penumpang di Kota Padang

\section{Daftar Pustaka}

Astuti, L. (2010). Strategi Kusia Bendi Dalam Menarik Penumpang. Skripsi. Universitas Negeri Padang.

Bruno. (2019). Persepsi Masayarkat Tentang Jasa Transportasi Berbasis Aplikasi Online di Kota Manado. Journal of Chemical Information and Modeling, 53(9), 1689-1699.

Bungin, B. (2010). Analisis Data Penelitian Kualitatif. Jakarta: Raja Grafindo Persada.

Elita, T.. (1993). Yang Berkelanjutan Terhadap Lingkungan di Perkotaan ( Studi Literatur ). 49-63.

Fatinah, B. S. (2005). Metode Penelitian Sosial Berbagai Alternatif Pendekatan. Jakarta: Kencana Prenadamedia Group.

Fitri, A. N., \& Putra, E. V. (2020). Rasionalitas Keberadaan Angkot Sebagai Transportasi Konvensional di Era Digital dalam Masyarakat Kota Padang. Jurnal Perspektif, 3(1), 79.

Jayanti, I. G. N. (2012). Pola Perilaku dan Pelayanan Sopir Angkot Kota di Kota Denpasar. Jurnal Budaya, 17(2), 250.

Kamaludin, R. (1976). Ekenomi Transportasi. Jakarta: Ghalia Indonesia.

Lantang, K. (2020). Analisis Efisiensi Pendapatan Supir Angkot Sesusdah Pasar Sentral Poso. Jurnal Ekomen, 20(1), 1-9.

Marcelena, M., Susilawati, N., \& Selinaswati, S. (2019). Respon Masyarakat Terhadap Penyimpangan Perilaku Oleh Sopir Angkot Rute Balai Baru-Pasar Raya Padang. Jurnal Perspektif, 2(4), 475-480.

Mahardika, G. (2017). Pola Komunikasi Dinas Perhubungan Kabupaten Karanganyar dalam Menanggulangi Kelebihan Muatan Penumpang pada Kendaraan Umum. Jurnal Mahardika, 7(2), 1-18.

Masful, M. F. (2017). Nilai Ikonik: Packaging Pada"Angkot Gaul" Kota Padang. Jurnal Studi Dokumentasi, 1(3), 262-270.

Moeleong, L. J. (2012). Metodologi Penelitian Kualitatif Edisi Revisi. Bandung: PT. Remaja Rosdakarya.

Purba, W. (2017). Analisa Persepsi Penumpang Terhadap Pelayanan Angkutan Umum Kota Padang. Jurnal Teknologi, 7(2), 169-182.

Putra, R. (2007). Sopir dan Angkot Gaul di Kota Padang.Skripsi. Universitas Negeri Padang.

Putranto, R. W. (2016). Strategi Adaptasi Dalam Menjaga Eksistensi Mikrolet.Skripsi. Malang: Universitas Airlangga.

Ritzer, G. (2004). Sosiologi Ilmu Pengetahuan Berparadigma Ganda. Jakarta: PT. Raja Grafindo.

Salim, A. (2006). Manejemen Transportasi. Jakarta: Rajagrafindo Persada.

Sari, I. P. (2016). Alasan Remaja Memilih Angkot Modifikasi Trayek Pasar Raya-Siteba Kecamatan Padang Utara Padang. Artikel Ilmiah

Soeparno, A. W. (2014). Permasalahan dan Pengembangan Angkutan Umum di Kota Surabaya. Jurnal Transportasi, 14(1), 53-60.

Sugiyono, S. (2016). Metode Penelitian Kualitatif, Kualitatif dan R\&D. Bandung: Alfabeta.

Syani, A. (2007). Sosiologi(Skematika, Teori, dan Terapan). Jakarta: PT. Bumi Aksara.

Yosritzal, Y \& Aulia, Q. (2016). Studi Pengaruh Penambahan Perangkat Audio Pada Angkutan Kota Padang Terhadap Jumlah Penumpang. Jurnal Ilmiah Rekayasa Sipil, 13(2), 51 . 